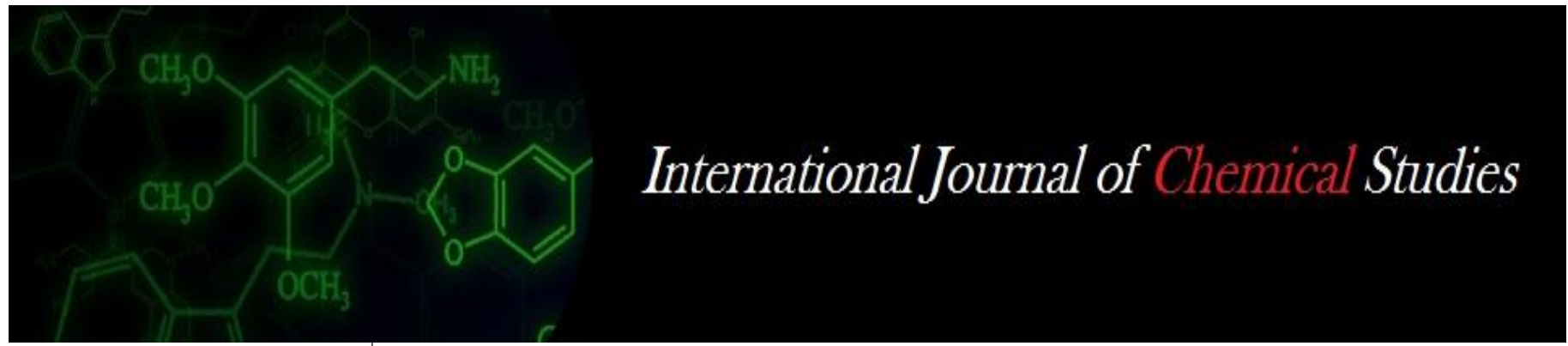

P-ISSN: 2349-8528

E-ISSN: 2321-4902

www.chemijournal.com

IJCS 2021; 9(1): 2002-2004

(C) 2021 IJCS

Received: 19-11-2020

Accepted: 24-12-2020

Reniguntla Chaitanya

M.Sc. Seed Science and

Technology, Sam Higginbottom

University of Agriculture,

Technology and Sciences,

Allahabad, Uttar Pradesh, India

Arun Kumar Chaurasia

Associate Professor, Department

of Genetis and Plant Breeding,

Sam Higginbottom University

of Agriculture, Technology and

Sciences, Allahabad,

Uttar Pradesh, India

Dega Dheerajkuma

M.Sc. Seed Science and

Technology, Sam Higginbottom

University of Agriculture,

Technology and Sciences,

Allahabad, Uttar Pradesh, India

M Sekhar

M.Sc. Agronomy,

Sam Higginbottom University of

Agriculture, Technology and

Sciences, Prayagraj,

Uttar Pradesh, India

Macherla Samson

M.Sc. Seed Science and

Technology, Sam Higginbottom

University of Agriculture,

Technology and Sciences,

Prayagraj, Uttar Pradesh, India

Corresponding Author: Reniguntla Chaitanya

M.Sc. Seed Science and

Technology, Sam Higginbottom

University of Agriculture,

Technology and Sciences,

Allahabad, Uttar Pradesh, India

\section{Effect of vermiwash, panchagavya and weed extract on growth, yield and seed quality parameters of cluster bean (Cyamopsis tetragonoloba $(\mathrm{L})$.)}

\section{Reniguntla Chaitanya, Arun Kumar Chaurasia, Dega Dheerajkuma, M Sekhar and Macherla Samson}

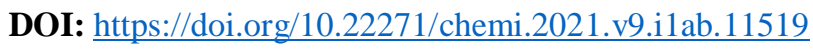

\begin{abstract}
Cluster bean (Cyamopsis tetragonoloba L.) popularly known as guar is a drought tolerant, deep-rooted, annual legume is grown for Vegetable, Food, Fodder, Green manure, Gum and as a seed. The fortification of seeds for better Growth and Yield has become important and emphasized. The study was conducted to determine the - Effect of Vermiwash, Panchagavya and Weed Extract on Growth, Yield and Seed Quality Parameters of Cluster bean (Cyamopsis tetragonoloba (L).). The experiment was carried out at Field Experimentation Centre of the Department of Genetics and Plant Breeding, Sam Higginbottom University of Agriculture, Technology \& Sciences. Prayagraj (UP) during Kharif-2019. The experiment was laid out in Randomised Blocked Design and comprised of 13 treatments and 3 replications. The treatments were T0 (Control), $\mathrm{T}_{1}$ - vermiwash 5\% @ 12hrs, T2 - vermiwash 10\% @ $12 \mathrm{hrs}, \mathrm{T}_{3}$ - vermiwash 15\% @ 12hrs, T4 - vermiwash 20\% @ 12hrs, T5 - panchagavya 5\% @ 12hrs, T6 panchagavya 10\% @12hrs, $\mathrm{T}_{7}$ - panchagavya 15\% @ 12hrs, $\mathrm{T}_{8}$ - panchagavya 20\% @ 12hrs, T9-weed seed extract 5\%@12 hrs, T10 - weed seed extract 10\%@12 hrs, T11-weed seed extract 15\%@12 hrs, $\mathrm{T}_{12}$ - weed seed extract 20\%@12 hrs.
\end{abstract}

Keywords: Cluster bean, treatment combinations, fortification, growth, yield

\section{Introduction}

Cluster bean (Cyamopsis tetragonoloba (L).) also known as gaur, guwar, or guvar bean is an annual self-pollinated leguminous crop and belongs to the family Fabaceae (Hymowitz and Matlock, 1963) ${ }^{[9]}$. The origin of the Clusterbean has been suggested in India and Pakistan and tropical Africa (Vavilov, 1951). It is assumed to have developed from the African species Cyamopsis senegalensis. It is a drought tolerant, deep-rooted, annual legume, used as vegetable, Seed, Green manure, Fodder. It is also used for making gum, which is used in Oil refinaries and Petroleum Industry. It is an important short duration (90120 days) crop of high nutritive valve having high nitrogen fixing ability and is grown during kharif as well as summer seasons in arid and semi-arid regions of India. Cluster bean is cultivated mostly in India, Pakistan, USA, Italy, Morocco, Germany, and Spain (Punia et al., 2009) ${ }^{[13]}$.

Young pods are good source of protein, carbohydrate, vitamins ('A' and 'C'), and important minerals like calcium and iron (Kumar and Singh 2002) ${ }^{[10]}$. The endosperm of guar seed contains an important hydrocolloid named galactomannan. Mucilaginous seed flour is used for making guar gum (galactomannan) utilized in textile, paper, cosmetic and oil industries throughout the world and is a useful absorbent for explosives (Smith, 1976). The galactomannan due to its thicker, binder and stabilizing specific qualities, has a diversified industrial applications viz. paper, food, cosmetics, explosives, mining, petroleum, pharmaceuticals and well drilling etc. Recent rise in demand of guar in International market as a gum is attributed to its use in mining industry and petrochemical, where its use as viscous agent has been revolutionized the petrochemical industry and resulted in considerable increase in global natural gas production (Falasca et al., 2015) ${ }^{[6]}$. 
The cluster bean gum used as: (i) agriculture - as anticrushing agent and water retainer, (ii) petroleum industry - as gelling and thickening agent, (iii) textile and juice industry - for sizing, as thickener and stabilizer, (iv) waste water purification - as a gelatinising agent, (v) explosives waterproofing agent, (vi) mining, and (vii) pharmaceutical industries (Girish et al., 2012) ${ }^{[7]}$. Because of its industrial value, guar seed has great demand from foreign countries like USA, Germany, Britain, Italy, France, UAE, China, Japan, South Africa, Hong Kong and Australia etc. Further, cluster bean meal (husk and germ) are used as high protein cattle feed (Rai and Dharmatti, 2013) ${ }^{[14]}$.

India is the major guar producer accounting for $80 \%$ of the world's production. In India, guar is being grown mainly in arid and semiarid regions of North Western states of Rajasthan, Gujarat, Haryana, Punjab, parts of Uttar Pradesh, Madhya Pradesh and Tamil Nadu. It is grown approximately in an area of 3.44 million ha, with a production of 2.21 million tonnes and has productivity of $644 \mathrm{~kg} / \mathrm{ha}$ (Directorate of Extension and Statistics, 2012) ${ }^{[4]}$. Rajasthan occupies the largest area under guar cultivation $(82.1 \%)$, followed by Haryana $(8.6 \%)$, Gujarat $(8.3 \%)$ and Punjab $(1 \%)$ which in turn produced 64, 22.12 and 2\% guar seeds, respectively (Pathak et al., 2010) ${ }^{[12]}$. Rajasthan is the largest producer accounting for $70 \%$ of total guar production of the country followed by Gujarat, Haryana and Punjab. The productivity of cluster bean ranges from $474 \mathrm{~kg} / \mathrm{ha}$ in Rajasthan to 1200 $\mathrm{kg} / \mathrm{ha}$ in Haryana (Ahlawat et al., 2013) ${ }^{[1]}$.

\section{Materials and Methods}

The Research study was conducted at experimental research field, Department of Genetics and Plant Breeding, Naini
Agriculture Institute, Sam Higginbottom University of Agriculture, Technology and Sciences, Prayagraj during kharif-2019. The experiment was carried out at Field Experimentation Centre of the Department of Genetics and Plant Breeding, Sam Higginbottom University of Agriculture, Technology \& Sciences. Prayagraj (UP) during Kharif-2019.

The source of seed material was obtained from Indian Institute of Pulse Research, Kanpur and the experiment was conducted in Randomized block design (R.B.D) with three replications and the genotype used in this Experiment was GR-6. The data was collected on five randomly selected plants from each plot and measurement of different observations was recorded. The treatments were represented as T0 (Control), $\mathrm{T}_{1}$ - vermiwash 5\% @ 12hrs, $\mathrm{T}_{2}$ - vermiwash 10\%@12hrs, $\mathrm{T}_{3}$ - vermiwash 15\%@12hrs, $\mathrm{T}_{4}$ - vermiwash $20 \% @ 12 \mathrm{hrs}, \mathrm{T}_{5}$ - panchagavya 5\% @ 12hrs, $\mathrm{T}_{6}$ panchagavya10\%@12hrs, $\mathrm{T}_{7}$ - panchagavya 15\%@12hrs, $\mathrm{T}_{8}$ - panchagavya 20\%@12hrs, T - weed seed extract 5\%@ $12 \mathrm{hrs}, \mathrm{T}_{10}$ - weed seed extract $10 \% @ 12 \mathrm{hrs}, \mathrm{T}_{11}-$ weed seed extract15\%@12 hrs, T 12 - weed seed extract 20\%@12 hrs.

\section{Result and Discussion}

Based on the present study, it can be concluded that the treatment combination T4 (vermiwash 20\%@12 hrs) is recommended as the best treatment combination for obtaining the batter growth, yield and quality parameters in cluster bean. Plant growth parameters such as Days to 50\% flowering, plant height, number of branches per plant, Number of pods per plant and yield parameters such as Number of cluster per plant, Number of pods per plant and seeds per pod. Mean performance of the plant growth parameters is shown in table-1.

Table 1: Mean performance of growth and yield parameters in cluster bean

\begin{tabular}{|c|c|c|c|c|c|c|c|c|c|}
\hline Treatments & $\begin{array}{c}\text { Field } \\
\text { emergence }\end{array}$ & $\begin{array}{c}\text { Days to 50\% } \\
\text { maturity }\end{array}$ & $\begin{array}{c}\text { Plant } \\
\text { height }(\mathbf{c m})\end{array}$ & $\begin{array}{c}\text { No. of } \\
\text { branches/plant. }\end{array}$ & $\begin{array}{c}\text { No. of } \\
\text { pods/plant. }\end{array}$ & $\begin{array}{c}\text { No. of } \\
\text { seeds/pods. }\end{array}$ & $\begin{array}{c}\text { Seed } \\
\text { yield/plant (g) }\end{array}$ & $\begin{array}{c}\text { Seed } \text { yield/plot (g) } \\
\text { (g) }\end{array}$ & $\begin{array}{c}\text { Biological } \\
\text { yield }\end{array}$ \\
\hline T0 & 70.00 & 44.00 & 97.21 & 7.27 & 45.73 & 6.67 & 3.11 & 40.12 & 156.47 \\
\hline T1 & 79.67 & 39.67 & 99.48 & 8.67 & 57.67 & 7.33 & 4.31 & 55.59 & 187.90 \\
\hline T2 & 83.00 & 40.33 & 111.05 & 8.90 & 62.00 & 11.13 & 7.05 & 90.91 & 285.44 \\
\hline T3 & 86.33 & 36.67 & 114.54 & 9.43 & 66.40 & 12.07 & 8.14 & 105.06 & 304.68 \\
\hline T4 & 88.67 & 35.67 & 116.33 & 9.97 & 68.33 & 12.63 & 8.81 & 113.59 & 318.04 \\
\hline T5 & 82.33 & 38.67 & 110.67 & 8.43 & 57.00 & 10.67 & 6.24 & 80.47 & 273.60 \\
\hline T6 & 77.00 & 42.37 & 103.66 & 6.33 & 58.33 & 8.67 & 5.16 & 66.61 & 216.47 \\
\hline T7 & 80.33 & 42.93 & 110.07 & 8.73 & 60.67 & 10.90 & 6.75 & 87.04 & 278.53 \\
\hline T8 & 85.67 & 37.67 & 113.83 & 9.10 & 65.67 & 11.67 & 7.88 & 101.62 & 309.94 \\
\hline T9 & 78.00 & 43.67 & 108.44 & 7.67 & 49.37 & 8.67 & 4.37 & 56.34 & 211.83 \\
\hline T10 & 80.33 & 38.40 & 112.67 & 8.33 & 52.33 & 9.33 & 4.98 & 64.28 & 231.41 \\
\hline T11 & 78.33 & 40.33 & 101.55 & 8.67 & 54.67 & 8.10 & 4.52 & 58.37 & 193.77 \\
\hline T12 & 74.67 & 42.67 & 110.43 & 8.33 & 56.33 & 9.67 & 5.56 & 71.70 & 249.50 \\
\hline Mean & 80.28 & 40.23 & 108.45 & 8.45 & 58.04 & 9.81 & 5.91 & 76.28 & 247.51 \\
\hline CV & 3.06432 & 9.03778 & 1.34398 & 7.25365 & 2.78559 & 12.6003 & 13.1245 & 13.1245 & 13.211 \\
\hline CD & $2.39504^{*}$ & 3.77519 & $1.43923^{*}$ & $0.61634^{*}$ & $1.64418^{*}$ & $1.33626^{*}$ & $0.86158^{*}$ & $11.1144^{*}$ & $35.8002^{*}$ \\
\hline SE. m & 1.42125 & 2.24025 & 0.85406 & 0.36574 & 0.97568 & 0.79295 & 0.51127 & 6.5954 & 21.2443 \\
\hline SE. d & 1.16044 & 1.82915 & 0.69734 & 0.29863 & 0.79664 & 0.64744 & 0.41745 & 5.38512 & 17.3459 \\
\hline
\end{tabular}

* Significant at $5 \%$ level of significance.

\section{Conclusion}

Treatment combination T4 (vermiwash 20\%@12 hrs) has maximum performance in all the plant growth and yield attributing characters and seed quality parameters it was followed by $\mathrm{T}_{3}$ (vermiwash $15 \%$ @ $12 \mathrm{hrs}$ ) and least performance was given by T0 (control) while compared with the other treatment combinations.

\section{References}

1. Ahlawat A, Pahuja SK, Dhingra HR. Studies on interspecific hybridization in Cyamopsis species. African J Agric 2013;8(27): 3590-3597.

2. Aravind Jukanti, Bhatt RK, Ramavtar Sharma, Kalia RK. Morphological, agronomic, and yield characterization of cluster bean (Cyamopsis tetragonoloba L.) germplasm accessions. J Crop Sci. Biotech. 2015;18(1):00-00.

3. Davies PJ. The plant hormones: their nature, occurrence, and functions. In PJ Davies, ed, Plant hormones: Physiology, Biochemistry and Molecular Biology. 
Kluwer Academic Publishers, Dordrecht, The Netherlands, 1995, pp 1 -12.

4. Directorate of Extension and Statistics, Government of India. Area, production, and productivity of clusterbean in India 2012.

5. Dodla Rajashekar Reddy, Saidaiah P, Ravinder Reddy K, Pandravada SR. Mean Performance of Cluster Bean Genotypes for Yield, Yield Parameters and Quality Traits. Int. J Curr. Microbiol. App. Sci 2017;6(9):36853693.

6. Falasca SL, Miranda C, Pitta-Alvarez S. Modeling an agroclimatic zoning methodology to determine the potential growing areas of Cyamopsis tetragonoloba (cluster bean) in Argentina. Advance Applied and Agriculture Sciences 2015;3:23-39.

7. Girish MH, Gasti VD, Thammaiah N, Kerutagi MG, Mulge R, Shantappa T et al. Genetic divergence studies in cluster bean (Cyamopsis tetragonoloba (L.) Taub.). Karnataka J Agric. Sci 2012;25:245-247.

8. Hari Singh Meena, Suneetha Devi KB, Suresh G. Yield and profitability of clusterbean (Cyamopsis tetragonoloba) as influenced by varieties and crop geometry in semi-arid climate of Andhra Pradesh. Indian Journal of Agronomy 2016;61(3):401-403.

9. Hymowitz T, Matlock RS. Cluster Bean in the United States. Oklahoma Agricultural Exper. Station Technical Bull 1963;611:1-34.

10. Kumar D, Singh NB. Guar in India. Scientific Publishers, Jodhpur, India, 2002, 1-5.

11. NRAA, Potential of Rainfed Guar (Cluster beans) Cultivation, Processing and Export in India. Policy paper No.3 National Rainfed Area Authority, NASC Complex. DPS Marg, New Delhi-110012, India, 2014, pp109.

12. Pathak R, Singh SK, Singh M, Henry A. Molecular assessment of genetic diversity in cluster bean (Cyamopsis tetragonoloba) genotypes. J Genet 2010;89:243-246.

13. Punia A, Yadav R, Arora P, Chaudhury A. Molecular and morphophysiological characterization of superior cluster bean (Cymopsis tetragonoloba) varieties. J Crop Sci. Biotechnol 2009;12:143-14.

14. Rai PS, Dharmatti PR. Genetic divergence studies in cluster bean (Cyamopsis tetragonoloba (L.) Taub.). Global J. Sci. Frontier Res. Agri. Veterinary 2013;13:1-5.

15. Renugadevi J, Vijayageetha V. Organic seed fortification in cluster bean (Cyamopsis tetragonoloba L.) TAUB. International conference on indigeneous vegetables and Legumes. Acta Hort, 2007, 335-338. 